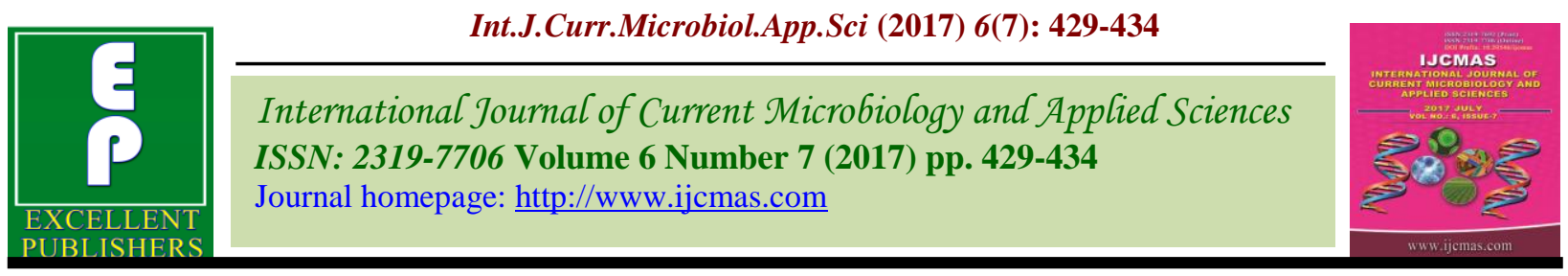

Original Research Article

https://doi.org/10.20546/ijcmas.2017.607.051

\title{
Studies on Effect of Glomus macrocarpum and Fluorescent Pseudomonads on the Population Density of Chilli Rhizosphere Microorganisms
}

\author{
V. Ramesha ${ }^{1 *}$, L. Krishna Naik ${ }^{1}$ and Y.M. Somashekhar ${ }^{2}$ \\ ${ }^{1}$ Department of Agricultural Microbiology, ${ }^{2}$ Department of Plant Pathology, College of \\ Agriculture, UAS, GKVK, Dharwad, Karnataka, India \\ *Corresponding author
}

\begin{tabular}{|c|c|}
\hline & A B S T R \\
\hline & \multirow{7}{*}{$\begin{array}{l}\text { The cost of inorganic fertilizers is increasing enormously, it has become impractical to } \\
\text { apply such costly inputs for crops and which makes soil unfertile. Use of biofertilizeris } \\
\text { practically advantageous, in these biofertilizers beneficial organisms are helpful in } \\
\text { phosphate solubilization, nitrogen fixation etc. They are known to improve growth and } \\
\text { yield of crop. The roots of chilli normally form a symbiotic association with AMF. In } \\
\text { mycorrhizal association, AMF has been shown to be beneficial to the host plant by } \\
\text { increasing nutrient uptake particularly N, P, K. Certain plant growth promoting rhizomicro } \\
\text { organisms has been reported to enhance the activity of AM fungi and consequently plant } \\
\text { growth. Hence, an experiment was conducted during the year } 2013 \text { under greenhouse } \\
\text { condition by using Byadagi dabbi variety of chilli and plant growth promoting } \\
\text { Pseudomonas and AM fungi at University of Agricultural Sciences, Dharwad, Karnataka. } \\
\text { The enhanced activity by rhizosphere microbial population such as phosphate solubilizers } \\
\text { and nitrogen fixers in rhizosphere soil was observed. The fluorescent pseudomonads and } \\
\text { AM fungi are known to produce certain plant metabolites, plant growth promoting } \\
\text { substances, vitamins, etc. Their synergistic interactions is said to be responsible for the } \\
\text { increased activity of micro flora and enzyme activity in rhizosphere. }\end{array}$} \\
\hline & \\
\hline & \\
\hline mycorrhizal fungi. & \\
\hline Article I & \\
\hline $\begin{array}{l}\text { Accepted: } \\
\text { 04 June } 20 \\
\text { Available } \\
\text { 10 July } 201\end{array}$ & \\
\hline & \\
\hline
\end{tabular}

\section{Introduction}

Chilli (Capsicum annum L.) is the fruit plant from the genus Capsicum, family Solanaceae, originated in the Central America. It turns pink after ripening due to the pigment capsanthin. It is a rich source of ascorbic acid. Chilli extracts are used in a wide range of medicines against tonsillitis, diphtheria, loss of appetite, flatulence, intermittent fever, rheumatism, sore throat, swelling and hardened tumors (De, 1992).

Today, India is the largest cultivator of chillies in the world and also one of the largest producers of chilli. In India, the area under chilli cultivation during 2001-02 was 9.4 lakh ha and the production was 10.30 lakh tonnes.

Capsaicin, the pungent principle in chilli is also used in several pain killers. Karnataka state stands second in area (1.90 lakh ha) and production (1.21 lakh tonnes) and eleventh in productivity (639 kg/ha) (Anonymous, 1999). Generally, solanaceous vegetables require a large quantity of major nutrients like nitrogen, phosphorus and potassium for better growth, fruit and seed yield. The cost of inorganic fertilizers is increasing enormously to an 
extent that they are out of reach of small and marginal farmers. And by using inorganic fertilizers and insecticides, the population of beneficial organisms decrease and natural regeneration of nutrition in the soil cease and soil becomes barren and soil fertility decreases. Use of fermented liquid manures in such situation is, practically advantageous. In these liquid manures, beneficial organisms survive and are helpful in phosphate solubilization, nitrogen fixation etc.

Arbuscular mycorrhizal association Improved plant growth was attributed to increased nutrient uptake especially phosphorus, tolerance to water stress and pathogens and adverse soil environments, production of growth promoting substances and synergetic interactions with other beneficial soil microorganisms (Azcon, 1989).

\section{Missing reference}

Several studies had shown beneficial interaction between plants and some endophytic bacteria, such as plant growth promotion and biocontrol potential against plant pathogens (Hallmann et al., 1995; Siddiqui and Ehteshamal, 2001).

Interactions between Pseudomonas fluorescens biocontrol agents and Glomus mosseae, an arbuscular mycorrhizal fungus, were studied. Where $G$. colonization of mosseae and activity of $G$. mosseae was unaltered in the presence of $P$. fluorescens isolates and presence of G. mosseae increased the population of $P$. fluorescens in the rhizosphere (Simon et al., 1998). Several Pseudomonas species have been shown to be effective in controlling pathogenic fungi and stimulating plant growth by a variety of mechanisms, including production of siderophores, synthesis of antibiotics, production of phytoharmones, enhancement of phosphate uptake by the plant, nitrogen $(\mathrm{N})$ fixation, and synthesis of enzymes that regulate plant ethylene levels (Bajpai and Sundar Rao., 1971).

Branching of the VAM fungus in root cortex (Gigaspora margarita) directly and indirectly through its effect on root exudation there by influences on rhizosphere micro flora (Treseder and Allen, 2002).

Edwards et al., (1998) reported that the presence of $G$. mosseae increased the population of $P$. fluorescens in the rhizosphere of tomato (L. esculentum) and leek (A. porrum), although the bacterium had no effect on the AM fungus. P. fluorescens performed better in terms of improving growth of tomato and leek when the bacterium was co-inoculated with Glomus mosseae. However, another plant growthpromoting bacterium, $P$. putida, which is taxonomically closely related to $P$. fluorescens, increased colonisation of roots by AM fungi (Meyer and Linderman, 1986; Gryndler and Vosátka, 1996).

\section{Materials and Methods}

\section{Estimation of fluorescent pseudomonads}

For the isolation of Pseudomonads, the Pseudomonas selective CFC2 supplement was added to the Pseudomonads agar base. The CFC supplement (Merck, India) is composed of the antibiotics cephaloridine, fucidin and cetrimide. These ingredients inhibit both Gram positive and Gram-negative accompanying micro flora and finally colony count was computed.

\section{Estimation of phosphate solubilizers}

The phosphate solubilizing microorganisms were isolated from the rhizosphere soil samples by dilution plate technique on Pikovskaya's agar medium (Pikovskaya, 
1948). The plates were incubated at $28+2{ }^{0} \mathrm{C}$ for seven days and colonies with clear zones around were counted. The representative colonies of each type of bacteria and fungi with clear zones around were purified, sub cultured and maintained on the slants of Pikovskaya's agar for further use.

\section{Estimation of free living nitrogen fixers}

The Nitrogen fixing Azotobacter strains were isolated from chilli rhizosphere soil samples and purified by using serial dilution method and plating on Noriss- $\mathrm{N}$ free agar media. Plates were incubated for five days at $30^{\circ} \mathrm{C}$. Small water droplets like glistening colonies which appeared on the medium were estimated for colony count, average value computed and colonies purified by repeated streaking on Norris $\mathrm{N}$ free agar medium. The purified isolates were transferred to the slants of the same medium and stored for further studies.

\section{Results and Discussion}

\section{Phosphate solubilizers}

The results pertaining to $\mathrm{P}$ solubilizers of chilli rhizosphere recorded at flowering and harvesting are presented in (Table 1) However, among the treatments, highest $\mathrm{P}$ solubilizers of 35.60 and $31.20 \mathrm{cfu} 10^{4} / \mathrm{g}$ of soil was observed in the treatment that received 50 per cent $\mathrm{RP}+$ Glomus macrocarpum + Fluorescent pseudomonads $\left(\mathrm{T}_{3}\right)$, at flowering and harvesting respectively. Among the inoculated treatments, the Treatments involving 75 per cent RP + Glomus macrocarpum + Fluorescent pseudomonads $\left(\mathrm{T}_{4}\right)$, and 50 per cent $\mathrm{SSP}+$ Glomus macrocarpum + Fluorescent pseudomonads $\left(\mathrm{T}_{6}\right)$, recorded the $32.14,32.68$ and $29.14,29.65 \mathrm{cfu} 10^{4} / \mathrm{g}$ of soil respectively, they were on par at flowering and harvesting stage. The lowest $\mathrm{P}$ solubilizers of 6.50 and $4.50 \mathrm{cfu} 10^{4} / \mathrm{g}$ of soil was recorded at flowering and harvesting in the treatments that maintained as uninoculated control, and the rest of the treatments were significantly comparable to each other.

\section{Nitrogen fixers}

The results pertaining to nitrogen fixers of chilli rhizosphere recorded at flowering and harvesting stage are presented in table 2 . Among the treatments, the highest nitrogen fixers of 26.66 and $21.18 \mathrm{cfu} 10^{4} / \mathrm{g}$ of soil at flowering and harvesting stages respectively was observed in the treatment that received 50 per cent RP + Glomus macrocarpum + Fluorescent pseudomonads $\left(\mathrm{T}_{3}\right)$,

Among the inoculated treatments, the treatments which received 75 per cent RP + Glomus macrocarpum + Fluorescent pseudomonads $\left(\mathrm{T}_{4}\right)$, and 50 per cent SSP + Glomus macrocarpum + Fluorescent pseudomonads $\left(\mathrm{T}_{6}\right)$, recorded $23.16,23.13$ and 19.07, $19.16 \mathrm{cfu} 10^{4} / \mathrm{g}$ of soil respectively, they were on par at flowering and harvesting stages. The lowest nitrogen fixers of 11.5 and $8.10 \mathrm{cfu} 10^{4} / \mathrm{g}$ of soil was recorded at flowering and harvesting in the treatments that maintained as uninoculated control, and the rest of the treatments were significantly comparable to each other.

\section{Fluorescent pseudomonads}

The results pertaining to the population of Fluorescent pseudomonas of chilli rhizosphere recorded at flowering and harvesting are presented in table 2. Among the treatments, the highest Fluorescent pseudomonads of 23.37 and $22.46 \mathrm{cfu} 10^{4} / \mathrm{g}$ of soil was observed in the treatment that received 50 per cent $\mathrm{RP}+$ Glomus macrocarpum + Fluorescent pseudomonads $\left(\mathrm{T}_{3}\right)$, at flowering and harvesting respectively. 
Table.1 Influence of Glomus macrocarpum and Fluorescent pseudomonads with Different source and levels of phosphorus on rhizospere population of

$\mathrm{P}$ solubilizers in chilli crop at flowering and harvesting

\begin{tabular}{|c|c|c|}
\hline \multirow{2}{*}{ Treatments } & \multicolumn{2}{|c|}{$\begin{array}{c}\text { Population of P solubilizers cfu } 10^{4} / \mathrm{g} \text { of } \\
\text { soil }\end{array}$} \\
\hline & $\begin{array}{r}\text { Flowering } \\
\text { (75 DAT) }\end{array}$ & $\begin{array}{c}\text { Harvesting } \\
\text { (135 DAT) }\end{array}$ \\
\hline $\begin{array}{l}\mathrm{T}_{1}-\text { Uninoculated control } \\
\mathrm{T}_{2}-\mathrm{GM}+\mathrm{FP} \mathrm{B} 25 \\
\mathrm{~T}_{3}-\mathrm{GM}+\mathrm{FP} \mathrm{B} 25+\mathrm{RP} 50 \% \\
\mathrm{~T}_{4}-\mathrm{GM}+\mathrm{FP} \mathrm{B} 25+\mathrm{RP} 75 \% \\
\mathrm{~T}_{5}-\mathrm{GM}+\mathrm{FP} \mathrm{B} 25+\mathrm{RP} 100 \% \\
\mathrm{~T}_{6}-\mathrm{GM}+\mathrm{FP} \mathrm{B} 25+\mathrm{SSP} 50 \% \\
\mathrm{~T}_{7}-\mathrm{GM}+\mathrm{FP} \mathrm{B} 25+\mathrm{SSP} 75 \% \\
\mathrm{~T}_{8}-\mathrm{GM}+\mathrm{FP} \mathrm{B} 25+\mathrm{SSP} 100 \%\end{array}$ & $\begin{array}{c}6.50 \\
28.30 \\
35.60 \\
32.14 \\
31.65 \\
32.68 \\
30.81 \\
28.28\end{array}$ & $\begin{array}{c}4.50 \\
23.30 \\
31.20 \\
29.14 \\
28.32 \\
29.65 \\
24.25 \\
24.20\end{array}$ \\
\hline $\begin{array}{c}\text { S.E.m } \pm \\
\text { CD }(0.01)\end{array}$ & $\begin{array}{l}0.26 \\
0.77\end{array}$ & $\begin{array}{l}0.18 \\
0.54\end{array}$ \\
\hline $\begin{array}{l}\text { : Glomus macrocarpum } \\
\text { : Fluorescent pseudomonads } \\
\text { : Rock phopshate } \\
\text { : Single super phosphate }\end{array}$ & & \\
\hline
\end{tabular}

Table.2 Effect of Glomus macrocarpum and Fluorescent pseudomonads with Different source and levels of phosphorus on rhizosphere population of free living nitrogen fixers in chilli crop at flowering and harvesting

\begin{tabular}{|c|c|c|}
\hline \multirow{2}{*}{ Treatments } & \multicolumn{2}{|c|}{$\begin{array}{l}\text { Population of free living } \mathrm{N}_{2} \text { fixers, cfu } \\
\qquad 10^{4} / \mathrm{g} \text { of soil } \\
\end{array}$} \\
\hline & $\begin{array}{l}\text { Flowering } \\
\text { (75 DAT) }\end{array}$ & $\begin{array}{l}\text { Harvesting } \\
\text { (135 DAT) }\end{array}$ \\
\hline $\mathrm{T}_{1}$ - Uninoculated control & 11.40 & 8.10 \\
\hline $\mathrm{T}_{2}-\mathrm{GM}+\mathrm{FP} \mathrm{B} 25$ & 18.36 & 12.20 \\
\hline $\mathrm{T}_{3}-\mathrm{GM}+\mathrm{FP} \mathrm{B} 25+\mathrm{RP} 50 \%$ & 26.66 & 21.18 \\
\hline $\mathrm{T}_{4}-\mathrm{GM}+\mathrm{FP} \mathrm{B} 25+\mathrm{RP} 75 \%$ & 23.16 & 19.07 \\
\hline $\mathrm{T}_{5}-\mathrm{GM}+\mathrm{FP} \mathrm{B} 25+\mathrm{RP} 100 \%$ & 21.18 & 17.53 \\
\hline $\mathrm{T}_{6}-\mathrm{GM}+\mathrm{FP} \mathrm{B} 25+\mathrm{SSP} 50 \%$ & 23.53 & 19.16 \\
\hline $\mathrm{T}_{7}-\mathrm{GM}+\mathrm{FP} \mathrm{B} 25+\mathrm{SSP} 75 \%$ & 20.91 & 18.05 \\
\hline $\mathrm{T}_{8}-\mathrm{GM}+\mathrm{FP} \mathrm{B} 25+\mathrm{SSP} 100 \%$ & 19.56 & 16.23 \\
\hline S.E.m \pm & 0.16 & 0.27 \\
\hline $\mathrm{CD}(0.01)$ & 0.46 & 0.78 \\
\hline \multicolumn{3}{|l|}{ : Glomus macrocarpum } \\
\hline \multicolumn{3}{|l|}{ : Fluorescent pseudomonads } \\
\hline \multicolumn{3}{|l|}{ : Rock phopshate } \\
\hline \multicolumn{3}{|l|}{ : Single super phosphate } \\
\hline
\end{tabular}


Among the inoculated treatments, the treatments involving 75 per cent RP + Glomus macrocarpum + Fluorescent pseudomonads $\left(\mathrm{T}_{4}\right)$, and 50 per cent SSP + Glomus macrocarpum + Fluorescent pseudomonads $\left(\mathrm{T}_{6}\right)$, recorded the of 22.47, 22 and 21.20, 21.55 , cfu $10^{4} / \mathrm{g}$ of soil respectively. And they were on par at flowering and harvesting. The lowest population of Fluorescent pseudomonads 6.10 and $4.30 \mathrm{cfu} 10^{4} / \mathrm{g}$ of soil was recorded at flowering and harvesting in the treatments that maintained as uninoculated control, and rest of the treatments are significantly comparable to each other.

The lowest spore count of 6.30 and $8.30 / 50 \mathrm{~g}$ of soil was recorded at flowering and harvesting in the treatments that maintained as uninoculated control, and the rest of the treatments were significantly comparable to each other.

The results pertaining to per cent root colonizationof chilli recorded at flowering and harvesting are presented in table 2 . Among the treatments, the highest per cent root colonization of 52.16 and 62.10 per cent was observed in the treatment that received 50 per cent RP + Glomus macrocarpum + Fluorescent pseudomonads $\left(\mathrm{T}_{3}\right)$, at flowering and harvesting respectively. Among the inoculated treatments, the treatments with 75 per cent RP + Glomus macrocarpum + Fluorescent pseudomonads $\left(\mathrm{T}_{4}\right)$, and 50 per cent SSP + Glomus macrocarpum + Fluorescent pseudomonads $\left(\mathrm{T}_{6}\right)$, recorded 42.13 and 42.73 per cent respectively, they are on par at flowering. The lowest per cent root colonization of 2.43 and 4.83 was recorded at flowering and harvesting in the treatments that maintained as uninoculated control and the rest of the treatments were significantly comparable to each other.

In conclusion, the inoculation of efficient Fluorescent pseudomonads and Glomus macrocarpum with rock phosphate showed significantly increase in the population of phosphate solubilizers, $\mathrm{N}_{2}$ fixers and fluorescent pseudomonads in chilli rhizosphere than absolute control. The $\mathrm{P}$ solubilizers, $\mathrm{N}_{2}$ fixers and Fluorescent pseudomonads at flowering recorded significantly higher population of (36.60, 26.66 and 23.37) due to co-inoculation of efficient FP + GM along with RP application compared to absolute control $(6.50,11.40$ and 6.10) and PF + GM (28.30, 18.36 and 18.50).

Colonisation of $G$. Mosseae and activity of $G$. mosseae was unaltered in the presence of isolates of $P$. fluorescens and presence of $G$. mosseae increased the $P$. fluorescens in the rhizosphere (Simon et al., 1998). Synergistic positive interactions have been reported between AM fungi and plant-growth promoting bacteria (PGPB) such as $\mathrm{N}$ fixers, fluorescent pseudomonads and sporulating Bacilli (Hameeda et al., 2007). Different arbuscular mycorrhizal fungal (AMF) species can differentially influence both the population and activity of Pseudomonads (Marschner and Crowley, 1996). Fluorescent pseudomonads like $P$. putida produce numerous metabolites such as plant growth regulators and vitamins, which affect the growth of plants and microorganisms present in soil (Hussain and Vancura, 1970). Although the mechanisms by which PGPRs promote plant growth are not yet fully understood. It is clear that auxin and siderophore production are two different mechanisms of plant growth stimulation (Kloepper et al., 1986).

\section{References}

Anonymous, 1999, Indian Agriculture. Indian Economic Data Research Center, New Delhi,

Azcon, R., 1989, Selective interaction between free living rhizosphere bacteria and vesicular arbuscular mycorrhizal fungi. Soil Biol. Biochem., 21: 639-644. 
Bajpai, P. D. and Sundara Rao, W. V. B., 1971, Phosphate solubilizing bacteria I. solubilization of phosphate in liquid culture by selected bacteria as affected by different pH values. Soil. Sci. and Pl. Nutri, 17: 4143.

De, A. K., 1992, A Chilli a day. Sci j., 30: 14-18.

Edwards, S. G., Young, J. P. W. and Fitter, A. H. (1998) Interactions between Pseudomonas fluorescens biocontrol agents and Glomus mosseae, an arbuscular mycorrhizal fungus, within th by plants. Plant and Soil 134: 189-207.

Gryndler, M. and Vosatka, M. 1996, the response of Arbuscular mycorrhizal fungus Glomus fistulosum to treatments with culture fractions from Pseudomonas putida. Mycorrhiza, 6: 207-211.

Hallmann, J., Kloepper, J. W, Rodriguez, K. R. and Sikora, A. 1995, Endophytic rhizobacteria as antagonists of Meloidogyne incognata on cucumber. Phytopathol, 85: 1136.

Hameeda, B. M., Srijana, O. P., Rupela, and Reddy, G. (2007) Effect of bacteria isolated from composts and macrofauna on sorghum growth and mycorrhizal colonization. World J Microbiol Biotechnol, 2 (6): 883887.

Hussain, A. and Vancura, V. 1970, Formation of biologically active substances by rhizosphere bacteria and their effect on plant growth. Folia Microbiol. 15: 468-478.

Kloepper, J. W., Scher, F. M., Laliberte, M. and Tipping, B. 1986, Emergence- promoting rhizobacteria: Description and implications for agriculture. In:) Iron, siderophores and plant disease. Swinburne TR (ed) Plenum. New York, pp: 155-164.

Marschner, P. and Crowley, D. E. 1996, Physiological activity of a bioluminescent Pseudomonas fluorescens (strain 2-79) in the rhizosphere of mycorrhizal and nonmycorrhizal peper (Capsicum annum L.). Soil. Biol. Biochem., 28: 869-876.

Meyer, J. R. and Linderman, R. G., 1986, Selective influence on populations of rhizosphere or rhizoplane bacteria and Actinomycetes by Mycorrhizas formed by Glomus fasciculatum. Soil Biol. Biochem., 18: 191-196.

Pikovskaya, R. I., 1948, Mobilization of phosphorus in soil in connection with vital activity of vesicular arbuscular mycorrhizae on tomato growth and soil microbial activity. Biol. Fert. Soil, 26(2): 79-87.

Siddiqui, I. A. and Ehteshamal, H. S., 2001. Suppression of the root rot-root knot disease complex by $P$. aeruginosa in tomato: The influence of inoculum density, nematode population, moisture and other plant associated bacteria. Plant Soil, 237: 81-89.

Simon Edwards, G., Peter Young, J. W. and Alastair Fitter, H. 1998, Interactions between Pseudomonas fluorescens biocontrol agents and Glomus mosseae, an arbuscular mycorrhizal fungus, within the rhizosphere. FEMS Microbiol, 16: 297-303.

Treseder, K. K. and Allen, M. F. 2002, Direct nitrogen and phosphorus limitation of arbuscular mycorrhizal fungi: a model and field test. New Phytol. 155: 507-515.

\section{How to cite this article:}

Ramesha, V., L. Krishna Naik and Somashekhar, Y.M. 2017. Studies on Effect of Glomus macrocarpum and Fluorescent Pseudomonads on the Population Density of Chilli Rhizosphere Microorganisms. Int.J.Curr.Microbiol.App.Sci. 6(7): 429-434. doi: https://doi.org/10.20546/ijcmas.2017.607.051 